\title{
"Impact of Relationship Quality on Firm's Export Profitability: A Study of SMEs in Gujarat"
}

\author{
Ms. Shivangi Singh, \\ Research Scholar, Institute of Management, \\ Nirma University, Ahmedabad \\ Plot 86/2, Sector - 8, Gandhinagar -382007Gujarat, India \\ Mob. No. 9377229467 E-mail: singhamazon1209@gmail.com
}

\section{Dr. Pawan Kumar Chugan,}

Professor, Institute of Management, Nirma University, Ahmedabad E-mail: pkchugan@imnu.ac.in

\begin{abstract}
:
The appearance of relationship quality paradigm in the field of international business has resulted in growing need to manage, develop and evaluate relationships amongst the exporters and importers besides influencing the profitability of the firm in the long-run. In the same light, the current study attempts to empirically examine the impact of relationship quality on firm's export profitability and increase the exporting firms understanding about the concept's utility in handling foreign market operations. Drawing data from small and medium sized exporting firms operational in Gujarat, the study reveals that relational dimensions of information sharing, longterm orientation and satisfaction with the relationship are statistically significant in impacting the firm's export profitability.
\end{abstract}

Keywords: Export Profitability, Relationship Quality, Relational Dimensions, Small and Medium Sized Firms.

\section{Introduction:}

Exporting is an important business activity impacting costs, sales, risk, and competitiveness of the exporting firms. It also plays a significant role in achieving sustainable competitive advantages by firms operating in turbulent markets because of the progress in financial position, increased capacity utilization, higher technological standards, and attainment of a desired performance (Leonidou and Katsikeas, 1996) ${ }^{1}$. Interest in exporting also is driven by the changing economic conditions across the world viz. growing liberalization, integration and global competition which are in turn responsible for the increasing engagement of firms in exporting activities.

In this increasingly competitive era, exporting firms need to invest in relationships with their importers to ensure effective and profitable actions. In an export setting, the relationship quality refers to relationships developed beyond national boundaries (Ural, 2009) ${ }^{2}$. Unlike the relationships in domestic market, relationships developed with buyers in foreign markets are predisposed to a higher degree by cultural dissimilarity, economic and other environmental factors. That is why, in the global context, empirical testing of relationship quality as a determinant of superior export performance by the firms, has been slower than conceptual development of the same (Samiee and Walters, 2003) ${ }^{3}$. The present study attempts to examine empirically the effect of relationship quality on the export performance of firms. It aims to throw light on the exporting firms' awareness regarding relationship quality, along with increasing their understanding about the concept's utility in handling foreign market operations.

\section{Relationship Quality Paradigm in Exporting:}

In the present competitive era, it is difficult for firms not to have relationships with other firms as they cannot function under isolation (Hakansson, 1982) ${ }^{4}$. Research has shown that firm's competitive advantage can be formed all the way through keeping 
long-term relationships with its customers and many firms are actually moving from transactional isolated exchanges to the more relational ones (Ganesan, $1994)^{5}$. The emergence of the relationship building paradigm in contemporary business scenario highlights the increasing importance given by managers to developing and evaluating relationships (Berry, 1995) ${ }^{6}$. The marketing logic behind this is that loyal buyers/customers generate more profits to the firms than the price-sensitive and deal-prone switchers (Reicheld, 1996) ${ }^{7}$. Also, committed relationships are among the most robust advantages because they are difficult for competitors to understand, to copy, or to displace (Day, 2000) ${ }^{8}$. Keeping pace with this paradigm, several firms are now actually realising the importance of relationship quality between them and their buyers/customers. Consequently, the role of relationship building has emerged as a top priority for most business firms around the world.

Research on exporter-importer relationships emerged in the early 1980 s, with the pioneering work of International Marketing and Purchasing (IMP) group (Hakansson, 1982) ${ }^{4}$. This body of research is based on the approach that exporting does not only involve economic transactions but also complex behavioral interactions as well, involving exchange of social, information, and other intangibles (Hallen \& Sandstrom, 1991) ${ }^{9}$. Understanding how to initiate, develop, and maintain high quality buyer-seller relationships in international markets is critical to achieve successful export involvement (Styles \& Ambler 1994)". In this regard, "Relationship Quality" is a vital facet for maintaining and evaluating buyer-seller relationships. It can be defined as "an overall assessment of the strength of relationship and the extent to which it meets the needs or expectations of the parties based on a history of successful or unsuccessful events" (Smith, 1998) ${ }^{11}$. Relationship quality is a complex construct having several distinct dimensions such as trust, commitment, and satisfaction (Smith, 1998) ${ }^{11}$, willingness to invest, conflict, expectation of continuity (Kumar, Scheer, \& Steenkamp, 1995) ${ }^{12}$, and minimal opportunism (Dwyer \& Oh, 1987) ${ }^{13}$. Earlier studies in this field mostly looked at the relationship quality as perceived by customer however, more recently, Lages et al., 2004 in their seminal work on developing the RELQUAL Scale looked at relationship quality from the perspective of the exporting firms. They adopted the organizational behavior instead of the consumer behavior approach. Relationship quality, hence, reflects the intensity of information sharing, communication quality, longterm orientation and satisfaction with the relationship between the exporter and importer (Lages, Lages \& Lages, 2004) $)^{14}$.

It is important to assess the relationships with importers because a business starts with the establishment of relationship between two parties and the maintenance of it via good habits (Ural, 2009) ${ }^{2}$. Most of the researchers have established that the relationship quality between two sides fosters the seller's performance outcomes. Earlier literature has measured relationship quality between different types of firms like service firms and their customers (Roberts, Varki, \& Brodie, 2003) $)^{15}$, between manufacturers/suppliers and distributors/resellers (Kumar, Stern \& Achrol, 1992) ${ }^{16}$ and between salespeople and customers (Bejou et al., 1996) ${ }^{17}$. Ural, $2009^{2}$ in his work measured the relationship quality between exporting firms and importers for Turkish SMEs, as SMEs tend to focus more on the relationship building aspect and thereby achieve business-related benefits like higher growth rates and lesser customer defections (Ural, 2009) ${ }^{2}$. The study hence, tried to look at the concept from the viewpoint of SMEs in India. The sample for the study is drawn from SMEs operational in Gujarat state of India. The study focuses on SMEs owing to the fact that small to medium-sized firms play an important role in nation's economy, accounting for a large part of its industrial base, with approximately 30 million SMEs in India, 12 million people expected to join the workforce in next 3 years and the sector growing at a rate of $8 \%$ per year (Europe-India SME Business Council, 2012) ${ }^{18}$. Despite of the strong presence in the economy, SMEs find it difficult to market their product effectively as compared to the large-scale firms and MNCs (MultiNational Companies). Consequently, they depend more on improving relations with the buyers as a tool for enhancing their sales and hence, achieve superior export performance.

\section{Conceptual Framework:}

Firms' survival and expansion, and the consequent economic growth of many countries, is strongly dependent on a better understanding of the determinants that influence their export performance. 
Export performance, in the international marketing literature, is defined as "the extent to which a firm's objectives (both economic and strategic) for exporting a product into a foreign market are achieved through planning and execution of export marketing strategy" (Cavusgil and Zou, 1994) ${ }^{19}$. Researchers have focused on three major export performance dimensions which largely incorporate important management areas. The first is the financial performance of the exporting activity which includes the use of such indicators like export sales, export sales growth (Madsen, 1987) ${ }^{20}$, export profitability (Madsen, 1987; Axinn, 1988; Johnson and Arunthanes, 1995) $)^{20,21,22}$,etc. The second dimension is based on capturing the strategic outcome of exporting. The key idea of this method is that firms often have a set of strategic goals in exporting which they desire to fulfil using various capabilities and resources available at their disposal (Cavusgil and Zou, 1994) ${ }^{19}$. This view holds that accomplishment of strategic goals such as improved competitiveness, increased market share or strengthened strategic position should be considered an integral part of export performance (Cavusgil and Kripalani, 1993) ${ }^{23}$. The third is the use of perceptual dimension measuring the satisfaction derived from exporting. The logic behind this is that satisfaction with export operations is a strong indication of management's successful stint in exporting. Studies using this perspective measures satisfaction with exporting (Cavusgil and Zou, 1994) $^{19}$, attitude towards exporting (Johnston and Czinkota, 1982) ${ }^{24}$, and attitude towards overcoming barriers to exporting (Bauerschmidt, Sullivan, and Gillespie, 1985) ${ }^{25}$. The present study adopts export profitability defined as "the executive's perception of earnings from export relative to the firm's total earnings" (Gencturk and Kotabe, 2001; Zou, Fang and Zhao, 2003; Brouthers et al, 2009; Al-Hyari et al., 2011) ${ }^{26,27,28,29}$, measured subjectively on a five-point Likert scale.

From the perspective of measuring relationship quality, the study builds on a multidimensional, validated and reliable measurement scale developed by Lages, C., Lages, C.R. and Lages, L.F. in 2004 to assess the relationship quality (RELQUAL) in exporting context. This multidimensional scale comprises of four dimensions: (1) amount of information sharing in the relationship, (2) communication quality of the relationship, (3) longterm relationship orientation and (4) satisfaction with the relationship. The individual items used in the scale were adopted from previous measurements scales from the strategy and relationship-marketing literature to formulate this more encompassing scale particularly for use in determining the exporterimporter relationships, for small and medium sized firms. Figure 1 shows the dimensions of relationship quality that have an effect on firm's export profitability.

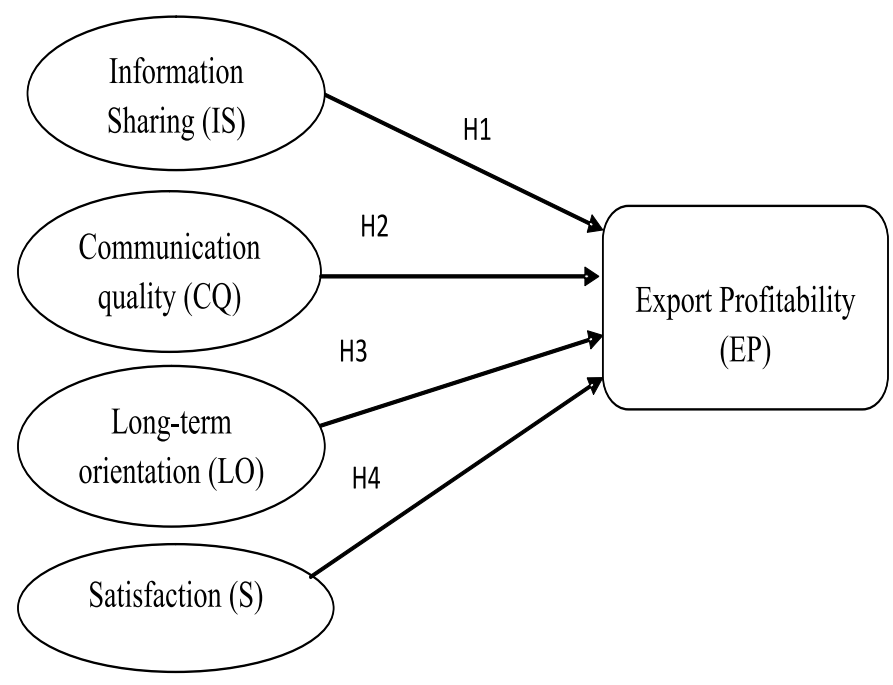

Figure.1. Conceptual Framework

\section{Amount of Information Sharing}

The amount of information sharing in the exporterimporter relationship is defined as the extent to which the exporter openly shares information that may be useful to the relationship with the importer, in the buyer-supplier context (Cannon \& Homburg, 2001) . $^{30}$. Information sharing is vital as it can strengthen relationships. By receiving information, the importer gets access to various advantages, like it can more easily predict exporter's future plans and adapt its own strategy to incur lesser costs (Lages, Lages, \& Lages, 2004) $)^{14}$. We thus, formulate the following hypothesis:

H1. Amount of information sharing is positively associated with export profitability.

\section{Communication Quality}

Communication quality is the extent to which there is a permanent interaction between the two parties of the dyad in charge of strategy making process (Menon, Bharadwaj, \& Howell, 1996) $)^{31}$. Communication quality of the relationship is considered as an intrinsic 
constituent element of the relationship quality as there is empirical evidence that the two concepts are related (Roberts, Varki, \& Brodie, 2003) $)^{15}$. Therefore, the next hypothesis could be stated as:

$\mathrm{H} 2$. Communication quality is positively associated with export profitability.

\section{Long-term relationship orientation}

Ganesan (1994) ${ }^{5}$ defined long-term relationship as the perception of mutual dependence of outcomes in such a way that joint relationships outcomes are expected to profit from the relationship in the long run. The long-term relationships offer significant sustainable competitive advantages to the firms. The argument is based on the logic that long-term relationships will foster cooperation, goal sharing and risk sharing between the parties, and hence, each side will expect that its own performance is also dependent on the relationship performance as a whole. Therefore, the hypothesis is framed as:

H3. Long-term relationship orientation is positively associated with export profitability.

\section{Satisfaction with the relationship}

Satisfaction with the relationship maybe defined as a positive emotional state resulting out of the assessment of the exporter's working relationship with the importer (Geyskens, Steenkamp, \& Kumar, $1999)^{32}$. Satisfaction with the relationship is considered to be a key dimension of relationship quality as it has been seen that more satisfied buyers have higher quality relationships with the selling firms (Dorsch, Swanson, \& Kelley, 1998) ${ }^{33}$. Hence, the final hypothesis can be stated as:

H4. Satisfaction with the relationship is positively associated with export profitability.

\section{Methodology:}

\section{Data Collection Procedure:}

The research setting is Gujarat State of India with data drawn from small and medium sized manufacturing exporters. A cross-sectional single source design is used where the unit of analysis is firm's latest export activity. An initial sample of 540 firms was randomly generated using the Gujarat business directory and the survey instrument i.e., questionnaire was administered via mail. A response rate of $15.74 \%$ was achieved, which is satisfactory, given the average managerial level survey response rates lie in the range of $\mathbf{1 1 - 2 0} \%$ (Menon, Bharadwaj, \& Howell, 1996) ${ }^{31}$. The final sample size of the study is hence, 85 firms. Scales used in the questionnaire are shown in Table 1.

\section{Table.1. Operationalization of Variables}

\begin{tabular}{|l|l|}
\hline Relationship quality scale (RELQUAL) [adopted from Lages et al., 2004] & $\boldsymbol{\alpha}$ \\
\hline Amount of information sharing in the relationship (IS): & 0.75 \\
V1 This importer frequently discussed strategic issues with us. & \\
V2 This importer openly shared confidential information with us. & \\
V3 This importer rarely talked with us about its business strategy (R). & 0.86 \\
\hline Communication quality of the relationship(CQ): & \\
V4 The parties involved had continuous interaction during implementation of the & \\
strategy. & \\
V5 The strategy's objectives and goals were communicated clearly to the & \\
involved and concerned parties. & \\
V6 Team members openly communicated while implementing the strategy. & \\
V7 There was extensive formal and informal communication during & \\
implementation. & \\
\hline Long-term relationship orientation (LO): & \\
V8 We believe that over the long -run, our relationship with the importer will be & \\
profitable. & \\
V9 Maintaining a long-term relationship with this importer is important to us. & \\
V10 We focus on long-term goals in this relationship. \\
V11 We are willing to make sacrifices to help this importer from time to time. & \\
\hline Satisfaction with the relationship (S): & \\
V12 Our association with this importer has been a highly successful one. \\
V13 This importer leaves a lot to be desired fro m an overall performance \\
standpoint (R). \\
V14 Overall, the results of our relationship with the importer were far short of \\
expectations (R). & \\
\hline Export Profitability (EP): & \\
\hline V15 Export Profitability (Executive's perception of earnings from export relativ e \\
to the firm's total earnings). & 0.79 \\
(R): reverse coded; all items are five point Likert scales anchored \\
by “strongly disagree" and 'strongly agree"; $\alpha=$ Cronbach's \\
alpha measure of reliability & \\
\hline
\end{tabular}

\section{Data Analysis:}

The Cronbach's Alpha reliability coefficients for all variables used were above 0.75 establishing the reliability of scales (Nunnally, 1988) ${ }^{34}$ (Table 1). Further, an examination of the correlations between the independent variables (Table 2) shows that correlation between constructs is low, not exceeding 0.301 , which suggests good discriminant validity (Malhotra and Dash, 2009) ${ }^{35}$. Multiple regression analysis was applied as the statistical tool for assessing the impact of predictor variables on export profitability. The results show that the overall fit of the model came out to be good, suggesting that the model is able to explain $67.3 \%$ of the variance in criterion variable due to the predictor variables. Looking at the individual dimensions of relationship quality, information sharing and long-term relationship orientation came out to be significant having p-values significant at $1 \%$ and $0.1 \%$ levels, followed by satisfaction with $\mathrm{p}$-value significant at $5 \%$ level. The result of the same is shown in Table 3 . 
Table.2. Descriptive Statistics: correlations, means and standard deviations $(\mathrm{N}=\mathbf{8 5})$

\begin{tabular}{|l|l|l|l|l|l|l|l|}
\hline & Mean & SD & 1 & 2 & 3 & 4 & 5 \\
\hline 1. Information Sharing & 4.000 & 1.100 & 1 & & & & \\
\hline 2. Communication Quality & 4.104 & 1.081 & $0.301^{*}$ & 1 & & & \\
\hline 3. Long-term Orientation & 3.563 & 1.550 & $0.300^{*}$ & 0.137 & 1 & & \\
\hline 4. Satisfaction & 3.111 & 1.173 & 0.150 & 0.209 & 0.110 & 1 & \\
\hline 5. Export Profitability & 16.783 & 15.121 & 0.231 & $0.299^{*}$ & 0.269 & 0.172 & 1 \\
\hline
\end{tabular}

Source: Authors Analysis; Significant at ${ }^{*} \mathrm{p}<0.01$

Table.3. Multiple Regression Analyses

\begin{tabular}{|l|l|}
\hline \multirow{2}{*}{$\begin{array}{c}\text { Independent Variables } \\
\text { Relationship Quality dimensions }\end{array}$} & Dependent Variable \\
\cline { 2 - 2 } & Export Profitability (EP) \\
\hline 1. Information Sharing (IS) & $0.344^{* *}(5.210)$ \\
\hline 2. Communication Quality (CQ) & $0.139(1.011)$ \\
\hline 3. Long-term Orientation (LO) & $0.475^{* * *}(6.772)$ \\
\hline 4. Satisfaction (S) & $0.220^{*}(3.014)$ \\
\hline $\mathrm{R}^{2}$ & 0.698 \\
Adjusted $\mathrm{R}^{2}$ & 0.673 \\
F & 21.678 \\
Significance & 0.000 \\
D-W Statistic & 2.011 \\
\hline Source: Authors Analysis; Significant at ${ }^{* * *} \mathrm{p}<0.001 ;{ }^{* *} \mathrm{p}<0.01 ;{ }^{*} \mathrm{p}<0.05$ \\
\hline
\end{tabular}

\section{Discussion:}

The results of this study show that while three relational dimensions of information sharing, long-term relationship orientation and satisfaction with the relationship are statistically significant and positive for the criterion variable export profitability; the relational dimension of communication proved insignificant. The significance of information exchange is explicable as it encourages the export profitability of small and medium sized firms. If exporters openly enter into contact with importer, share confidential information and discuss strategic issues, continuation with export activity will be prolonged. Managers must frequently discuss strategic issues with their importers. This would enable the importer to easily predict exporter's future plans and adapt its own strategy to it, bringing competitive advantage to both the parties in terms of export profits and growth of market share.
Long-term relationship is also vital as it offers significant sustainable competitive advantages to the firms (Ganesan, 1994) ${ }^{5}$. The argument is based on the logic that long-term relationship will perhaps induce cooperation, goal sharing and risk sharing. Moreover, they could work in a cooperative manner, avoiding the short-term alternatives and focussing on long-term paybacks.

Satisfaction with the relationship also impacts the profitability of the firm. It can bring out fruitful consequences for the firms like decision to work together, satisfactory working relationships, choosing to work together again, hoping for a long-lasting relationship and happy working relationship (Calantone \& Gassenheimer, $1991)^{36}$. Such factors are expected to have direct positive impact upon sales ratios and lead to market expansion for the exporting firms.

However, 'Communication quality in the relationship' has found to be not linked to export profitability. 
The insignificant effect of this dimension can be attributed to differences in culture and distance between two countries, creating a lack of more frequent communication in the international context. Distance may interrupt the communication flow between the trade parties, which is imperative in keeping them adequately informed. Furthermore, owners of small businesses due to distance do not completely know the language codes and cultural dynamics of importers.

\section{Conclusion:}

The relationship quality of exporter with importer is an integral part of firm's export overall marketing strategy and have an impact on its profitability. Leonidou, Katsikeas, \& Samiee $(2002)^{37}$ highlights the importance of relationship quality as an essential ingredient of exporting strategy which is linked directly to export profitability. From this point of view, the direct effect of relationship quality on firm's export profitability was analyzed in this study.

Relationship quality reflected the intensity of information sharing, long-term orientation and satisfaction with the relationship between exporter and importer, as the key dimensions impacting performance. The sharing of information by managers with people who are regularly in touch with the importer, and asking their importers for suggestions strengthens the bond of trust between the two parties. Firms should reward employees that show greater relational contacts, deal with and exceed their importers expectations, and communicate frequently with the importers thereby establishing elongated ties. In current age of extreme price competition, exporting firms often complain about complexity of differentiating their products from those of its competitors. The answer to this intense competition lies in developing a differentiation strategy by using non-price competition methods. For this purpose, the long-term oriented managerial view assures the maintenance of long-term relationship with importer, further culminating into a significant competitive advantage for the firm, where exporting firms can differentiate themselves from their competitors via good relationships with importers. Finally, the ultimate aim of marketing is to create satisfaction in the mind of customer, by building value-laden relationships with them. SMEs should develop and maintain successful relationships to ensure satisfaction on the part of the importers. By forming strategies that deal satisfactorily the with relationship quality, managers can eventually control their firm's export profitability and could contribute to maximization of the effectiveness of marketing mix. SME exporters can therefore, set themselves apart from global competitors through maintaining good relationships with their importers in the international markets.

\section{References}

1. Leonidou, L.C., \& Katsikeas, C.S. (1996). The Export Development Process: An Integrative Review of Empirical Models. Journal of International Business Studies, Vol.27, No.3, 517-551.

2. Ural, T. (2009). The effects of relationship quality on export performance: A classification of small and medium-sized Turkish exporting firms operating in single export-market ventures. European Journal of Marketing, Vol.43 Iss: 1.

3. Samiee, S., \& Walters, P.G. (2003). Relationship marketing in an international context: a literature review. International Business Review, Vol. 12 No. 2, 193-214.

4. Hakansson, H. (1982). International Marketing and Purchasing of Industrial Goods: An Interaction Approach, John Wiley \& Sons, Chichester.

5. Ganesan, S. (1994). Determinants of long-term orientation in buyer-seller relationships. Journal of Marketing, 58(April):1-19.

6. Berry, L.L. (1995). Relationship marketing of services-growing interest, emerging perspectives. Journal of Academic Marketing Sciences, Vol. 23 No. 4, 236-45.

7. Reicheld, F. F. (1996). The Loyal Effect, Harvard Business School Press.

8. Day, G. S. (2000). Managing Market 
Relationships. Journal of the Academy of Marketing Science, 28(1):24-30.

9. Hallen, L., and Sandstrom, M. (1991). Relationship atmosphere in international business, in Paliwoda, S.J. (Ed.). New Perspectives on International Marketing, Routledge, London.

10. Styles, C., and Ambler, T. (1994). Successful export practice: the UK experience. International Marketing Review, 11, 23-47.

11. Smith, J.B. (1998). Buyer-seller relationships: similarity, relationship management, and quality. Psychological Marketing, Vol. 15 No. 1, 3-21.

12. Kumar, N., Scheer, L.K., \& Steenkamp, J.E. (1995). The effects of supplier fairness on vulnerable resellers. Journal of Marketing Research, Vol. 32 No. 1, 5-65.

13. Dwyer, F.R., \& Oh, S. (1987). Output sector munificence effects on the internal political economy of marketing channels. Journal of Marketing Research, 24(4):347-58.

14. Lages, C., Lages, C.R., \& Lages, L.F. (2004). The RELQUAL scale: a measure of relationship quality in export market ventures. Journal of Business Research, 58(2005), 1040-1048.

15. Roberts, K., Varki, S., \& Brodie, R. (2003). Measuring the quality of relationships in consumer services: an empirical study. European Journal of Marketing, Vol. 37 No. 1, 169-96.

16. Kumar N, Stern L, Achrol R. (1992). Assessing reseller performance from the perspective of the supplier. Journal of Marketing Research, 29(5):238-53.

17. Bejou, D., Wray, B. \&Ingram, T.N. (1996). Determinants of relationship quality: an artificial neural network analysis. Journal of Business Research, 36(2):137-43.

18. Europe-India SME Business Council. (2012). http://www.eisbc.org accessed on $20^{\text {th }}$ July, 2013 at 7:08pm.

19. Cavusgil, S.T. and Zou, S. (1994). Marketing strategy - performance relationship: an investigation of the empirical link in export market ventures. Journal of Marketing, 58, $1-21$.
20. Madsen, T.K. (1987). Empirical Export Performance Studies: A Review of Conceptualizations and Findings, in Cavsugil, S.T. (ed.). Advances in International Marketing, Greenwich, CT; JAI Press, 2:177-198.

21. Axinn, C.N. (1988). Export performance do managerial perceptions make a difference? International Marketing Review, Vol. 5, Summer, 61-71.

22. Johnson, J.I., \& Arunthanes, W. (1995). Ideal and actual product adaptation in US exporting firms. International Marketing Review, Vol. 12 No. 3, 31-46.

23. Cavusgil, S.T. and Kirpalani, V.H. (1993). Introducing products into export markets: success factors. Journal of Business Research, 27, 1-15.

24. Johnston, W.J., and Czinkota, M.R. (1982). Managerial Motivations as Determinants of Industrial Export Behavior in Export Management: An International Context, M.R.Czinkota and G.Tesar, eds. New York: Praeger Publishers.

25. Bauerschmidt, A., Sullivan, D., and Gillespie, K. (1985). Common Factors Underlying Barriers to Export: Studies in the U.S. Paper Industry. Journal of International Business Studies, 16 (Summer), pp.65-82.

26. Gencturk, E.F. and Kotabe, M. (2001). The Effect of Export Assistance Program Usage on Export Performance: A Contingency Explanation. Journal of International Marketing, Vol.9 No.2.

27. Zou, S., Fang, E. and Zhao, S. (2003). The Effect of Export Marketing Capabilities on Export Performance: An investigation of Chinese Exporters. Journal of International Marketing, Vol.11, No.4,pp. 32-55.

28. Brouthers, L.E., Nakos, G., Hadjimarcou, J. and Brouthers, K.D. (2009). Key Factors for Successful Export Performance for Small Firms. Journal of International Marketing, Vol.17, No.3, pp.21-38.

29. Al-Hyari, K. and Abutayeh. (2011). Exporting Performance and Manufacturing Activities in Jordanian SMEs: External Barriers and Relationships. International Journal of Global 
Business, 4(1), 44-72.

30. Cannon, J.P., and Homburg, C. (2001). Buyersupplier relationships and customer firms' costs. Journal of Marketing, Vol. 65, January, 29-43.

31. Menon.A., Bharadwaj, S.G., \&Howell, R.D. (1996). The quality and effectiveness of marketing strategy: effect of functional and dysfunctional conflict in intraorganizational relationships. Journal of Academic Marketing Sciences, 24(Fall):299-313.

32. Geyskens, I., Steenkamp, J.B., \& Kumar, N. (1999). A meta-analysis of satisfaction in marketing channel relationships. Journal of Marketing Research, Vol. 36 No. 2, 223-38.

33. Dorsch, M.J., Swanson, S.R., \& Kelley, S.W. (1998). The role of relationship quality in the satisfaction of vendors as perceived by customers. Journal of Academic Marketing Sciences, Vol. 26 No. 2, 128-42.
34. Nunnally, J.C. (1988). Psychometric Theory. McGraw-Hill Book Company, EngelwoodCliffs, NJ.

35. Malhotra, N.K., \& Dash, S. (2009). Marketing Research - An Applied Orientation, $5^{\text {th }}$ edition, Pearson/Prentice Hall.

36. Calantone, R.J., \& Gassenheimer, J.B. (1991). Overcoming basic problems between manufacturers and distributors. Industrial Marketing Management, Vol. 20, 215-21.

37. Leonidou, L.C., Katsikeas, C.S., \& Samiee, S. (2002). Marketing strategy determinants of export performance: a meta analysis. Journal of Business Research, Vol. 55, 51-67. 